\title{
Insight
}

\section{Conflicts Associated with Dam Removal in Sweden}

\author{
$\underline{\text { Anna G. C. Lejon }}^{1}$, Birgitta Malm Renöfält ${ }^{1}$, and $\underline{\text { Christer Nilsson }}^{1}$
}

\begin{abstract}
The increasing number of deteriorating old dams that need renovation or have lost their function make dam removal a viable management option. There are at least four major reasons for dam removal: safety, law and policy, economy, and ecology. Here we discuss 17 Swedish dams that were recently considered for removal. Because dam removal usually causes controversy, dam removal initiatives may succeed, fail, or result in a compromise such as a bypass channel for migrating fish. We identify and discuss three major obstructions to dam removal: funding, cultural-historical values, and threatened species. To facilitate dam removal, the reasons for, and the effects of, dam removal must be carefully explained, and the public and stakeholders must be kept informed. In complicated cases in which compromise solutions may be the most feasible outcome, the integration of the knowledge of different stakeholders is crucial. The involvement of diverse stakeholders increases their willingness to find compromises, thus avoiding conflicts and failures.
\end{abstract}

Key Words: controversies; dam removal; information; obstructions; reservoirs; rivers; stakeholder involvement; Sweden

\section{INTRODUCTION}

During the 20th century, humans dammed and regulated most of the world's rivers for reasons such as hydropower, flood control, domestic water supply, and navigation (Nilsson et al. 2005). Globally, there are now about 50,000 dams exceeding $15 \mathrm{~m}$ in height (WCD 2000), and many new dams are planned or under construction (WWF 2004). There is no current record of the global number of small dams, i.e., dams $<15 \mathrm{~m}$ in height, but in the United States alone there are approximately 2 million such dams (Shuman 1995). Among Sweden's more than 5300 dams, about 5100 (96\%) are small (SMHI 1994, 1995, Vattenportalen 2007). Although human control over freshwater flow has increased prosperity for many people, it has also led to serious effects on ecosystems and local human societies (e.g., Nilsson and Berggren 2000, Scudder 2005).

Dams increase water retention, modify the hydrograph, eliminate turbulent reaches and riparian wetlands, impede the dispersal and migration of plants and animals, decrease interactions between land and water, and reduce sediment transport (Ward and Stanford 1995, Jansson et al. 2000, Kingsford 2000, Syvitski et al. 2005). Following the creation of dams and reservoirs, many terrestrial ecosystems become permanently inundated. This damages ecological communities, erodes the soil of the inundated land (Dudgeon 1995, Nilsson et al. 1997), and causes emissions of greenhouse gases such as methane and carbon dioxide during the breakdown of organic matter (Fearnside 1997, St. Louis et al. 2000). Even if not directly affected by loss of property, humans are often indirectly affected by hampered ecosystem services such as reduced water availability on farmed floodplains following decreased flooding, lowered aquatic productivity, and reduced control of species invasions (Nilsson et al. 2005).

During the Swedish dam-building era after World War II, large, modern hydroelectric power plants were constructed to supply the developing industry and society with electric power. In some cases, small dams, such as hydroelectric dams and splash dams used for timber floating, were removed to make room for larger ones. In this respect, dam removal is not a new concept in Sweden. However, the removal of entire impoundments and dam 
constructions to restore riverine landscapes is a new practice. Thus, dam removal is becoming a more frequently used management option, especially for old dams in need of renovation and small dams that are no longer used or have lost most of their reservoir capacity. Globally, most dams that have been removed or considered for removal are in the USA. In 2003, Stanley and Doyle (2003) reported that more than 500 dams had been removed in the previous two decades in the United States, although they found no data indicating that any other country had removed more than nine.

Dam removal is now becoming a viable option in other regions of the world for several reasons. For the dam owner, removal can be economically preferable to renovation because of the environmental benefits gained from the restoration of turbulent stream reaches and fish migration routes. Safety reasons are also vital, especially in cases in which dams are in bad shape and hold large amounts of water (Stanley and Doyle 2003). Despite such benefits, however, dam removal often gives rise to conflicts. This is the case even when dam owners encourage removal. Conflicts often result in unnecessarily long processing times, and sometimes removals are stalled even in cases in which funding for removal has been provided. In this paper we address incentives for dam removal such as safety issues, law and policies, and economic as well as ecological incentives. We also outline some of the underlying mechanisms of the types of conflict associated with dam removal. Our presentation is based on our own experience with recently debated and implemented dam removals in Sweden (Table 1). We also provide guidance on how conflicts can be prevented or resolved in future dam removals.

\section{INCENTIVES FOR DAM REMOVAL}

Early dam removals were often motivated by safety considerations but, during the 1990s, environmental motives became more prevalent. In some cases, removal offers direct economic advantages. We here discuss four drivers of dam removal: (1) safety, (2) law and policy, (3) economics, and (4) ecology.

\section{Safety}

All dams have limited life spans, and dams that are not maintained eventually fail (David and Baish 2002, Palmer et al. 2008). Numerous dams around the world are in need of inspection, because dams at risk of failure as a result of future climate changes and possible severe floods may pose serious threats to humans and infrastructure. Climate change is predicted to alter global water cycling, and, within $40 \mathrm{yr}$, some of the largest rivers may have doubled the amount of water they discharge. Impounded rivers are not designed for discharge outside their range of variability, which makes them less capable of managing these alterations compared to freeflowing rivers (Palmer et al. 2008).

Dams may also fail because of reservoir sedimentation (Evans et al. 2000). The sedimentation rate is highest during floods and violent storms, and even mudslides caused by earthquakes can have unpredictable effects on reservoir sedimentation. Changing climates may cause more intense storms that will probably increase the rate and unpredictability of sedimentation (Emanuel 2005, Webster et al. 2005). For example, one of the worst dam collapses in history occurred in Henan province, China, in August 1975. The Banqiao dam was built on the Huai River, a tributary of the lower Yangtze, and was considered to be an indestructible dam that could never fail. When a typhoon and a cold front collided over Henan province, the Banqiao reservoir filled to close to maximum capacity in a single day. Even though its sluice gates were open, they became partly blocked by sediment, which caused the water level of the reservoir to rise to more than $2 \mathrm{~m}$ above its designed capacity in $24 \mathrm{~h}$. The dam collapsed the next day, and $500 \mathrm{Mm}^{3}$ of water rushed downstream at a speed of $50 \mathrm{~km} / \mathrm{h}$, drowning entire villages and towns. This precipitated the failure of as many as 62 dams, causing the deaths of 230,000 people (McCully 2001).

In a more recent example from May 2008, a major earthquake struck eastern Sichuan, China, with a magnitude of 7.9 on the Richter scale. More than 69,000 people were killed, and the earthquake was felt in most of central, eastern, and southern China (U.S. Geological Survey 2008). In the southern parts of the Quangxi region, rain and floods after the earthquake exerted tremendous pressure on six dams that were in danger of bursting, and people were evacuated downstream from one of the dams, 
Table 1. A list of Swedish dams and rivers subjected to/considered for restoration and the issues involved in the process.

\begin{tabular}{lcccccc}
\hline \hline Name & River & $\begin{array}{c}\text { Height } \\
(\mathrm{m})\end{array}$ & Built & Removed & Original use & $\begin{array}{c}\text { Reason for removal/ } \\
\text { compromise }\end{array}$ \\
\hline $\begin{array}{l}\text { Gate } \\
\text { kvarndamm }\end{array}$ & Gatebäcken & 3 & 1880 & $\begin{array}{c}\text { Not } \\
\text { removed }\end{array}$ & Water mill & Facilitate fish passage
\end{tabular}

Issues: The dam owners wanted to keep their lake and were not in favor of a removal without compensation. Financial difficulties because of expensive consultants led to a compromise in the form of a fish passage. This later came to nothing, and the dam was left intact.

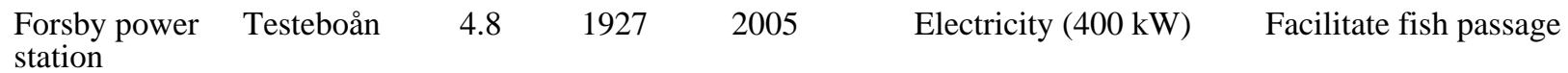

Issues: The power company and local politicians opposed removal and argued that removal would trigger a chain reaction leading to dam removals all over Sweden. Some years later, the power station was no longer profitable, and extensive dam renovations were required. A removal was agreed upon. Adjacent neighbors opposed removal to the very end mainly because they feared a dried-up ditch would result.

$\begin{array}{llllll}\begin{array}{l}\text { Unnefors } \\ \text { dam }\end{array} & \text { Nissan } & 2.3 & 1924 & 2007 & \begin{array}{c}\text { Sawmill/ } \\ \text { electricity }\end{array}\end{array}$

Issues: Adjacent neighbors wanted to keep the impoundment for recreational purposes. The dam owner, a sawmill company, was opposed to removal at first but changed its mind when a second alternative was presented. They had one condition: that the natural channel be redug further to the northeast to provide the mill with an extended timber yard in the former impoundment.

\begin{tabular}{|c|c|c|c|c|c|c|}
\hline Kuba dam & Nätraån & 3 & 1974 & 2007 & $\begin{array}{l}\text { Storage reservoir for process } \\
\text { water used in factories }\end{array}$ & $\begin{array}{l}\text { Abandoned dam, facilitate } \\
\text { fish passage and reproduction } \\
\text { of freshwater pearl mussel }\end{array}$ \\
\hline
\end{tabular}

Issues: The local fishing organization had been advocating the removal of this dam for many years but was not able to raise the money needed. The county administration eventually wrote a petition, and funding and permission were granted.
Bultfallet
Kolbäcksån
4.2
1923
Replaced
Electricity $(800 \mathrm{~kW})$
Abandoned dam

Issues: The power company got permission to remove the dam, which was abandoned and decaying, but the municipal council was concerned with cultural-historical values. The cultural committee strongly opposed a removal, and local inhabitants were afraid that the scenery would change dramatically after a removal. The old dam was eventually removed and replaced with a new one.
Bruksfallet
Kolbäcksån
4.3
1906
Replaced
Electricity $(900 \mathrm{~kW})$
Abandoned dam

Issues: Same as above. 


\begin{tabular}{|c|c|c|c|c|c|}
\hline Rödå dam & Rödån & 4.5 & 1940 & $\begin{array}{c}\text { Not } \\
\text { removed }\end{array}$ & $\begin{array}{l}\text { Water mill/ } \\
\text { electricity }\end{array}$ \\
\hline
\end{tabular}

Issues: The dam owner strongly opposes a removal and continues to put up resistance.

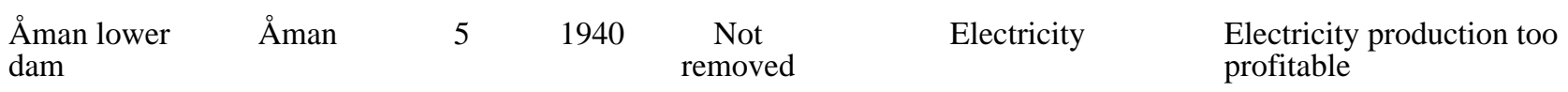

Issues: Removal is probably not possible because of high electricity production. The construction of a fish passage is under discussion.

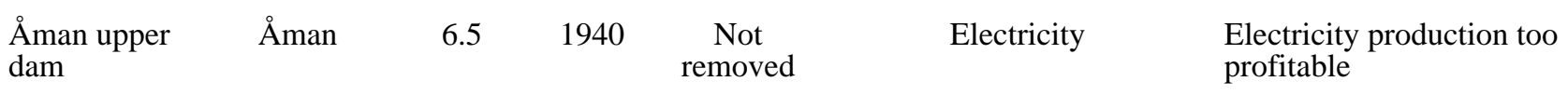

Issues: Same as above.

Emsfors dam Emån $3.5 \quad \begin{gathered}\text { Not } \\ \text { known }\end{gathered} \begin{gathered}\text { Not } \\ \text { removed }\end{gathered}$ Electricity $\quad \begin{aligned} & \text { Facilitate fish passage, } \\ & \text { increase biodiversity }\end{aligned}$

Issues: The former dam owner refused to agree to necessary environmental measures. The new dam owner agreed to a removal, but an adjacent property owner is now impeding the process by trying to get compensation. There are also concerns regarding the wels catfish (Silurus glanis) population, which is one of the few remaining in Sweden; a complete removal would have to include extensive work to maintain a suitable catfish habitat.

Franshammars Harmångersån
dam $\begin{gathered}\text { Not } \\ \text { known }\end{gathered} 1918 \quad 2002 \quad \begin{aligned} & \text { Water mill/ } \\ & \text { electricity }\end{aligned} \quad$ Facilitate fish passage

Issues: Adjacent neighbors were concerned about low water levels upstream if the dam were removed. Hälsingland Museum claimed that the dam had historical value and should have been left intact.

Sörtjärns dam Harmångersån $\begin{gathered}\text { Not } \\ \text { known }\end{gathered} \quad \begin{gathered}\text { Not } \\ \text { known }\end{gathered} \quad 2002 \quad$ Water mill $\quad$ Facilitate fish passage

Issues: Same as above.

Hisjö dam $\begin{gathered}\text { Visboån/ } \\ \text { Flysån }\end{gathered} \quad 3 \quad \begin{gathered}\text { Not } \\ \text { known }\end{gathered} \quad 2007 \quad$ Electricity $\quad$ Increase biodiversity

Issues: There were no obstacles.

Hillman's
mill $\quad$ Norralaån $\quad 2.8 \quad 1912 \quad \begin{gathered}\text { Not } \\ \text { removed }\end{gathered} \quad \begin{aligned} & \text { Water mill/ } \\ & \text { electricity }\end{aligned} \quad$ Facilitate fish passage

Issues: In 2006, a fish passage was built so that the dam could be conserved for tourism.

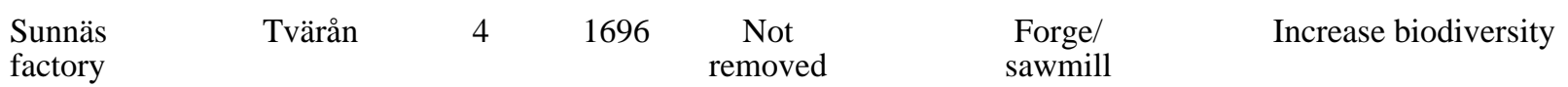

Issues: The forge and the adjacent mansion are both classified as cultural heritage sites, so dam removal was not an option. The fish passage that was built in 2005 blends in esthetically with its surroundings. There was no opposition because of good communication, and a solution was found that appealed to everyone involved. 


Kvarn dam Söderhamnsån $1.5 \quad 1751 \quad \begin{gathered}\text { Not } \\ \text { removed }\end{gathered} \quad$ Water mill Facilitate fish passage

Issues: The cultural committee and the environmental departments at the municipal office and the county administration worked closely together so that upcoming problems could be solved without opposition or conflicts.

\begin{tabular}{|c|c|c|c|c|c|}
\hline Långbo dam & Skärjån & 1918 & $\begin{array}{l}\text { Not } \\
\text { removed }\end{array}$ & $\begin{array}{l}\text { Water mill/ } \\
\text { sawmill/ } \\
\text { electricity }\end{array}$ & $\begin{array}{l}\text { Facilitate fish passage, } \\
\text { increase biodiversity }\end{array}$ \\
\hline
\end{tabular}

Issues: The removal of this dam is still under discussion, and an optimal solution is hard to find. The dam is located very close to the main road. Even though it is in bad condition, the village association would like to keep it. Any future fish passage must be designed to take the location into account.

which had a reservoir capacity of $1.8 \mathrm{Mm}^{3}$ of water (Ruwitch 2008).

These facts make it necessary, at some point in time, to assess a dam's future, no matter what the reasons were for building it and irrespective of whether it is being used or not. In the case of nonfunctioning or unused dams and reservoirs, there are good grounds for removing them completely to avoid the hazards caused by dam failures. The most common cause of dam and reservoir aging is sediment filling. For example, in a review of reservoirs in Romania, Rãdoane and Rãdoane (2005) found that some of them were half filled with sediment within $50 \mathrm{yr}$. In the most extreme cases, artificial reservoirs can completely fill with sediment within 10-20 yr (Einsele and Hinderer 1997, Kelly 1997). A dam with a sediment-filled reservoir no longer fulfils its original purpose and, if it collapses, could cause devastating turbidity and sediment deposition in reaches further downstream. In reservoirs with low sedimentation rates, constraints on dam construction become critical for their life-span.

\section{Law and policy}

Water issues are now receiving a high priority on the political agenda because of increasing knowledge about the negative consequences of human water usage. In many countries, dam removals are supported by national policy and legislation related to the protection and enhancement of biodiversity in freshwater ecosystems. For example, in Sweden, the Environmental Objectives state 16 ecosystem goals that should be reached by the year 2020 (Swedish
Government 2008). The objective that has the most relevance for freshwater ecosystems concerns the responsibility of maintaining flourishing lakes and streams, good-quality groundwater, thriving wetlands, and a rich diversity of plant and animal life (Swedish Government 2008). One subgoal to be accomplished while achieving this overall objective is that $25 \%$ of valuable and potentially valuable rivers and streams must be restored by 2010.

Strong regional laws and policy instruments may also be an imperative for dam removal. By signing the European Union Water Framework Directive, member states have agreed to manage all water in an ecologically sustainable way and to maintain its ecological status (European Commission 2000). Furthermore, the European Union Natura 2000 network and the Habitat Directive oblige the member states to ensure the restoration or maintenance of natural habitats (European Commission 1992). Within these directives lie both the opportunity and the obligation to restore waters that have been degraded, such as those impacted by dams. In comparison, in the USA two separate acts, the Federal Power Act (FPA) and the Endangered Species Act (ESA), play vital roles in the licensing and relicensing of hydroelectric power dams through the Federal Energy Regulatory Commission (FERC). The ESA was formed to protect species and the ecosystems in which they exist, whereas the FPA regulates the development of power. Today, in U.S. relicensing processes, dam operators must consider the impact of their operations on the riverine environment and the possibility of taking preventive measures to mitigate negative impacts. The ESA thus has a compelling effect on the 
relicensing permissions handled by FERC (Blumm and Nadol 2001).

\section{Economic incentives}

Under some circumstances it may be economically more beneficial to remove a dam than to keep it, even if it still produces revenue. For example, a study of 14 dam removals in Wisconsin, USA, showed that the estimated cost of repair was on average three times higher than that of removal (Born et al. 1998). One common consequence of damming rivers is an impoverished fish fauna. Fish production is often an important source of income for local inhabitants, both directly as fish harvest and indirectly as a resource base for tourism and recreational fishing. The loss of income caused by the loss of fishing can be greater than the value of the power produced (Kruse and Scholz 2006). The restoration of fishing can therefore be a strong incentive for removing dams.

A recent survey among anglers who had visited the Storsjö fisheries conservation area in central Sweden revealed that the dam at Storsjö-Kapell influenced the value that the anglers placed on the catch (Laitila et al. 2006). If the dam were removed, the economic value of a large fish would double and the value of a fishing-day would increase by an average of 537 Swedish kronor (SEK), even with no change in the fish stock. It has been estimated that a dam removal would make it possible to quadruple fish stocks, which would increase the value of a fishing-day by 1830 SEK. Such a scenario would increase the number of fishing-days per season by $72 \%$, from 2000 to 3440 (Laitila et al. 2006).

In the United States, considerable resources are spent every year on preserving threatened fish species in regulated rivers (Revenue Stream 2008). In the Columbia River Basin, the transportation of juvenile chinook salmon by trucks from the uppermost dams to the lowest dam has considerably slowed the rate of decline of that species. Without that specific aid, the salmon would probably have disappeared from the Snake River. The removal of the lower Snake River dams might increase the physiological vigor of the salmon that swim downstream and improve their survival (Kareiva et al. 2000). Dam removal would end the need for outof-river fish transportation, which probably has added to the annual costs of maintaining the dams
(Revenue Stream 2008). Dam removal is now increasingly seen as a viable alternative to maintenance, and even larger dams are being considered for removal, the two dams on the Elwha River providing one of the best examples.

The Elwha and Glines Canyon dams on the Elwha River in Washington State, USA, were built in 1913 and 1927, respectively, and are scheduled for removal in 2012. The upper portion of the Elwha river basin is located within Olympic National Park, and the lower reach at the river's mouth is in the Klallam Indian reservation. This tribe was the first to demand dam removal, and its members pointed out that the river formed an integral part of their spiritual heritage and that the dam construction was a tremendous injustice. For the tribe, dam removal is of great importance because of deeply held cultural and personal beliefs. Because the tribe also relies economically on salmon fishing, restored fish production would be of great financial value. The two dams were built without fish ladders, although state law at that time required them, and they therefore disrupt salmon migration and block off approximately $90 \%$ of their spawning habitat (Gowan et al. 2006, Duda et al. 2008, Pess et al. 2008). Another case in which the removal of a dam would provide economic benefits is that of Sweden's indigenous Sami people, especially those who herd reindeer, an activity that has been profoundly affected by dams and reservoirs in northern Sweden. For example, the availability and quality of reindeer pasture lands have decreased because of the inundation of river valleys, and the passage of rivers during migration periods has become difficult because of modified flow and ice conditions. Some compensation has been given to the Sami people for damage and intrusion, but these funds are not considered adequate compensation for the difficulties caused (Morin 2006).

\section{Ecological incentives}

Dams alter many natural characteristics of and processes in rivers. For example, by fragmenting channels and modifying flows, they affect the productivity of wetlands, floodplains, and deltas; disrupt the migration and dispersal of riparian and aquatic organisms as well as sediment dynamics; and cause freshwater species numbers to decline (Hart and Poff 2002, WWF 2004). Many dams with large reservoirs, especially those that have hypolimnetic release of water, also modify the 
temperature regime of downstream reaches and lead to shifts in biota (e.g., Gregory et al. 2002). In general, impounded rivers are considered to favor the invasion of non-native species, thus exerting further pressures on the biota (Stanford et al. 1996, Johnson et al. 2008).

Although dams and reservoirs have many ecological effects, the disruption of the movement of different organisms is probably the most important reason for removing dams. Dam removal makes it possible for fish passage and fish taxa to shift from lentic to lotic species, which have the potential to migrate and reproduce along free-flowing watercourses (Hart et al. 2002, Stanley and Doyle 2003). The St. Etienne de Vigan dam on the Upper Allier River, a tributary of the Loire River in France, may serve as an example. This dam was removed in 1998 to provide access to salmon spawning grounds. The removal was part of the French government's program to restore the salmon population in the Loire basin, and the aim was to have 6000 salmon return to the estuary in 2008 and to ensure the environmental protection of the Loire River. The river has returned to a near natural state, and, in the winter of 19981999, five salmon spawning sites were found upstream of the former dam (RiverNet 2008).

As mentioned, dam removal is beneficial to migrating fish, and eel is a species that has suffered a severe reduction in stock numbers because of dam constructions. European eel (Anguilla anguilla) spend most of their lives in fresh water in northern Europe. However, they breed in the Sargasso Sea, so that free passage to the sea is crucial for spawning (Laffaille et al. 2005, Acou et al. 2008). Also, the migration route of eels has changed because of dam constructions that add significantly to the difficulties of spawning (Degerman et al. 2001). Sea trout (Salmo trutta) is another example of a fish species impeded by dams, not only during its upstream spawning journey but also on its way back to the sea. Apart from newly spawned adults, smolts experience a dangerous journey downstream trying to pass dam constructions without getting killed in the turbines (Coutant and Whitney 2000). Common whitefish (Coregonus lavaretus) spawn in lakes, streams, or the sea. During the summer months, the species moves toward colder and deeper waters (Swedish Board of Fisheries 2008), and free passage is a prerequisite for its natural migration patterns.

Climate change may also be an important reason for dam removal (cf. above). Although many rivers will face increased discharge in the future, others may experience a considerable flow reduction. With increasing temperatures, reservoirs in warm and dry areas will lose even more water through evaporation in addition to the approximately $3.5 \%$ that now evaporates every year. The fact that reservoirs trap large amounts of sediment reduces the nutrient supply to the sea and causes coastal deltas to shrink (Ericson et al. 2006, Palmer et al. 2008). Dam removal could thus be a feasible means of adapting to escalating climate change (Palmer et al. 2008). Also, in the future we will need replacement water supplies and far more effective and equitable conservation measures if and when reservoir storage is diminished because of dam removal.

Dam removal is also a feasible method of restoring habitats, flow patterns, and migration paths. It is possible to restore these three riverine components more or less separately or in different combinations depending on the results required. The initiative to remove dams originated quietly in the USA as early as 1931, when a dam on the Idaho River was removed, but the movement has continued to grow, and, with Secretary of the Interior Bruce Babbitt as spokesman, the issue was brought into the U.S. political arena (Klein 1999). As mentioned above, in Sweden the practice of using dam removal as an ecological restoration method is rather new.

\section{DAM REMOVAL IN SWEDEN}

In Table 1 and Fig. 1 we present a compilation of the cases of 17 dams in different parts of Sweden that have all been considered for removal. In six of the 17 examples, the dams have been completely removed, five to improve fish passage and one to increase general biodiversity. The creation of fish passage was one of the reasons for removal in 12 of the 17 examples, and it was the only reason in seven of those 12 . Increased biodiversity was a reason for removal in five of the 17 examples, and it was claimed as the only reason in three of those five. Small-scale electricity production was a main or subordinate use for 11 of the 17 dams. These examples provide a general idea of the work done and of the issues and incentives entailed in the removal and decision-making processes. Table 1 also points out that the work involved various kinds of problems, including strong wills, contrasting opinions, and, at times, misconceptions rooted early on in the process. Three cases, all located within the same municipality, constitute a specific situation 
because, despite contrasting opinions, everyone involved was willing to work for a consensus.

\section{CONTROVERSIES ASSOCIATED WITH DAM REMOVAL}

Given the many negative consequences of dams for ecosystems, one would assume that, if a dam owner decided to remove an old, inefficient dam, people would support that decision. However, this is often not the case. Instead, dam removal operations are often subjected to a number of different obstacles that may postpone or stop the process. One might wonder why dams are seen as monuments of human engineering skills, or why they raise indignant feelings in proponents as well as opponents of removal. The U.S. politician and dam removal proponent Bruce Babbitt said,

\section{I always wonder what is it about the sound} of a sledgehammer on concrete that evokes such a reaction? We routinely demolish buildings that have served their purpose or when there is a better use for the land. Why not dams? For whatever reason, we view dams as akin to the pyramids of Egypt-a permanent part of the landscape, timeless monuments to our civilization and technology.

Born et al. (1998) studied the process leading to the removal of 14 dams in Wisconsin, USA, and found that, in all cases, citizens originally opposed removal when it was first discussed at stakeholder meetings. The most vocal opponents in their study were riparian landowners and the local communities around the impoundments. In cases in which riparian landowners represented a majority of stakeholders, i.e., dams were located in the middle of communities rather than more rural settings, the dams ended up being repaired instead of removed, despite a higher cost for the dam owner. Born et al. (1998) also categorized the perceived gains and losses following removal and found that stakeholders in 12 of the 14 cases felt that improved safety was a gain. Stakeholders also listed improved fish and wildlife habitats as a reward.

Despite the fact that many Swedes are highly aware of ecological matters and willing to pay for healthy ecosystems (Sundberg and Söderqvist 2004), ecological values must frequently take a back seat when money and reluctance, which often originate from fear of change and the unknown, come to play vital roles in dam removal processes. Even strong arguments for removal may not convince opponents. People tend to have major misconceptions about what will happen after a dam is removed, and there is a common misunderstanding that the removal of a dam will alter the scenery in a negative manner, for instance, that there will be nothing left but a pool of mud (Sarakinos and Johnson 2003). For example, this was the main objection to the removal of the Unnefors Dam (Table 1; B. Lind, personal communication). Orr and Stanley (2006) showed that vegetation established quickly following dam removal and that less than $1 \%$ of all sampled areas was bare sediment even on sites restored as recently as a year previously. We also saw the rapid recolonization of the soil of the former reservoir after the Kuba dam was removed (Table 1, Fig. 2). Measurements of production capacity in this former reservoir also showed that it was significantly higher compared to reference sites, probably because of nutrient-rich sediments and good access to sunlight (Hörnström 2009). If people are not familiar with the meaning of words such as "change" and "restoration," they easily give them negative connotations. Therefore, neighboring landowners and people living adjacent to a dam tend to oppose the idea of dam removal.

Owners of dams and land play important roles in the decision-making process, but, unfortunately, their opinions are often based on inaccurate facts (David and Baish 2002, Graf 2003). Public education is needed to overcome these misconceptions. We as humans have tried to disassociate ourselves from natural cycles and processes by altering the structure and dynamics of ecosystems so as to satisfy our immediate needs and desires. Today's conflicts between different societal "needs" involve an attempt to communicate that humans belong to ecosystems worldwide. Decades of successive disassociation from nature leave many people perplexed when the integration of human societies and ecosystems is called for (Bradshaw and Bekoff 2001). There are numerous dam removals in Sweden that have come to a halt primarily because of reluctance (cf. above). People wish to keep their lake for recreational purposes rather than gaining free-flowing water. Another common misunderstanding is that dam removal will cause property values to drop (Sarakinos and Johnson 2003, Provencher et al. 2008).

In 2006, we undertook a project to examine the ecological effects of dam removal in Sweden. This project followed a comparative design in which we 
Fig. 1. Locations of the Swedish streams and dams studied (see also Table 1).

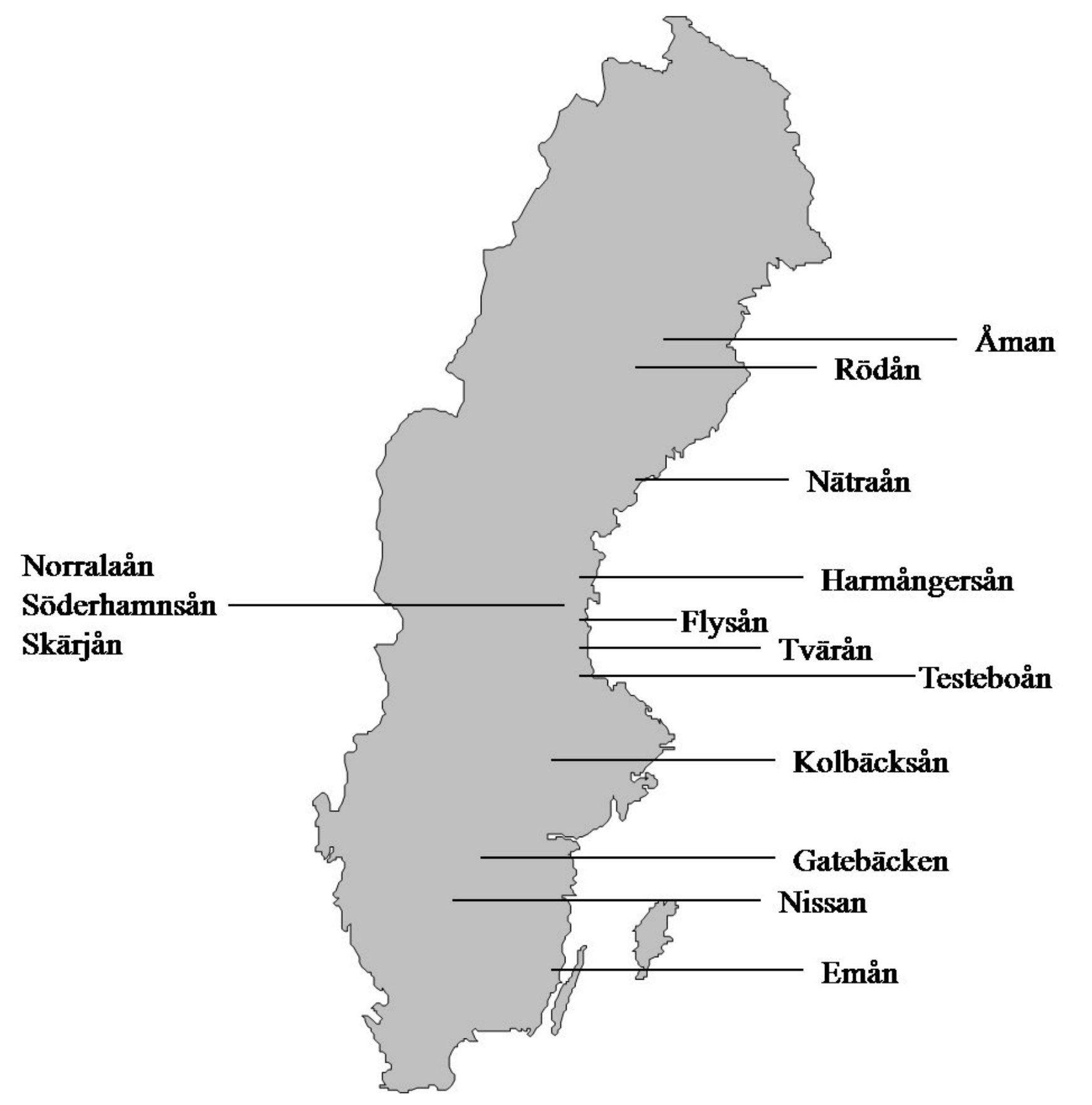


Fig. 2. Recolonization of vegetation on the soils of the former reservoir upstream of the Kuba dam occurred within a few months after dam removal. (A) The former reservoir in May 2007, (B) the same site in September 2007.

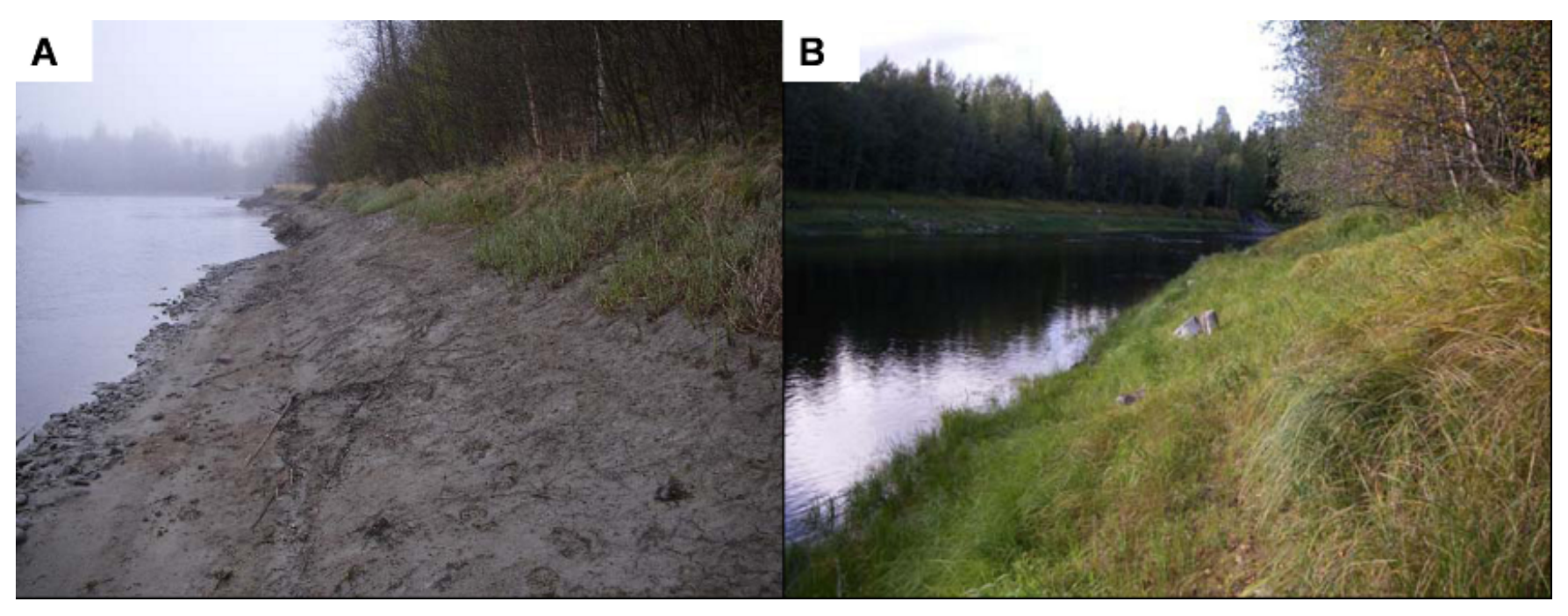

matched dammed sites with reference sites that had not been affected by dams before and after dam removal (cf. Stewart-Oaten et al. 1986). Because of changes in plans at the municipal or county administrative level, we experienced setbacks in our fieldwork. For various reasons, dam removal plans often change late in the approval process, and several dams that had been close to removal suddenly met with opposition. In a couple of cases, we had actually begun pre-removal studies, and a few months before a planned removal the process unexpectedly came to a halt because of a sudden lack of funds, stakeholder reluctance, or new demands from landowners and neighbors. We report on some of these obstacles and discuss their causes. We have identified three generic obstructions to dam removal:

1. Financing. Financial support to cover the costs is often difficult to obtain because usually funding from several sources is required.

2. Cultural-historical values. These values are often in conflict with the needs of the ecosystem. Co-operation and a constructive exchange of ideas would facilitate negotiations.
3. Threatened species. These species are subject to intense protection programs. Even though laws and regulations are in place to help preserve viable populations of threatened and endangered species in their natural habitats, it can be difficult to balance what society wants with the needs of the ecosystem.

The two cases (Gatebäcken and Kolbäcksån) presented in more detail were chosen mainly because they differ substantially from each other and because they represent issues that need to be addressed. Here reluctance also played a significant role in the negotiations and decision-making process. Experts, scientists, public authorities, and others need to become better at pointing out and communicating the various positive effects of dam removal.

\section{Funding obstacles}

Funding is one of the major obstacles to dam removal and one that makes it difficult to forecast the outcome of removal plans. Usually, funding has to come from different sources because expenses are typically too high to be covered by a single funder (Babbitt 2002). Whitelaw and Macmullan 
(2002) present six analytical principles that should guide the analysis of the economic consequences of a decision to remove a dam. These deal with issues related to benefits as well as costs, rights and responsibilities, uncertainty, and sustainability. To properly argue for removal and allocate funding, it is thus important to have a clear picture of the economic consequences of dam removal. There is no guarantee that available funding will cover all the costs involved in the process. Consulting firms, contractors, landowners requesting compensation for intrusion, and others all require their share of the allocated funds.

For example, in 1880, a dam was built on Gatebäcken in Hjo municipality, Sweden, to provide a Norse mill with water, and in 1924 a generator was installed to supply the mill with electricity for lighting. This dam was due for removal in 2007, when plans changed mainly because of insufficient funding. The consulting firm hired to write the proposal requesting the removal permit turned out to be more expensive than expected, and when the magnitude of the sediment layers in the reservoir and the costs involved in excavating them became clear, there was no other option than to suspend the removal plans. The municipality's allocated funds were not sufficient to compensate the dam owner as well as carry out a complete removal. Instead, it was decided that a fish passage should be built and that the embankment and spillways should be strengthened to keep the impoundment intact. A year later, however, there were no funds left, and for the moment no measures are being taken with regard to this dam.

Another example is the removal of the Elwha and Glines Canyon dams on the Elwha River. As part of the deal, the federal government had to provide a new water treatment plant, a new fish hatchery, and other mitigation projects. These constructions added significantly to the costs and time required to remove the dam (National Park Service 2007, Dunagan 2008, Gawley 2008). Because a large portion of the watershed is within Olympic National Park, which is managed by the National Park Service, this constitutes an ideal setting for studying the effectiveness of river restoration techniques, thus perhaps paving the way for future large-scale restorations. The U.S. government bills this project as the largest decommissioning project in history, and perhaps this fact, along with collaboration among stakeholders and unique study opportunities, keeps the project going even though the costs are greatly inflated (Duda et al. 2008).

\section{Cultural-historical obstacles}

The cultural-historical values of dams and associated constructions are other stumbling blocks to dam removal, no matter how much those structures are impinging upon the needs of the ecosystem. In Sweden, as in other countries, there are many old industrial communities, and the mills and factories are often attractive old buildings with preservation value. Dams used by the hydroelectric power industry may have been in place for a long time and have become accepted and valued parts of the environment (e.g., Klein 1999). In such cases, balancing the importance of functional ecosystems and cultural-historical values is an arduous task. When working to identify watercourses with high conservation value, the Swedish EPA and several county administration boards have cooperated with the National Heritage Board to find common ground in their judgments.

One example is the stream Kolbäcksån, which is impounded by several dams and runs through the old Swedish industrial community of Hallstahammar, which has a metal industry as its core business. Two of these dams, Bruksfallet and Bultfallet, are old and in bad condition, so it would be desirable to remove them. The dams were built in 1906 and 1920 , respectively, to supply several factories with electricity, but in 1989 a new and more efficient dam fully replaced these and two other dams. The power company that owns the dam was given court permission for removal, but the municipal council felt that it would be too large an intrusion into the cultural-historical environment and the process came to a halt. After examining these concerns, the municipal council reached a unanimous decision that the dams would not be removed but left intact. As of today, an appeal has been lodged, and negotiations have reached a deadlock. Fear of losing recreational opportunities may be another factor influencing this decision, because the communities living close to the reservoir use it for swimming, fishing, and boating. Some of the early opposition to removing the Elwha dam came from people who liked to go boating and fishing in the reservoirs ( $\mathrm{J}$. Helfield, personal communication). Because a reservoir often becomes central to a community's sense of place and is taken to be a natural part of the environment, it can be difficult to persuade people 
to change their minds. Klein (1999) elegantly illustrates this point in her presentation of the pros and cons of emptying Lake Powell on the Colorado River.

\section{The obstacle of threatened species and the risk of spreading invasive species}

Chapter 7, Section 11, of the Swedish Environmental Code states that small land and water areas that constitute habitats for endangered animal and plant species or are otherwise particularly worthy of protection may be designated habitat protection areas, and that activities or measures that are liable to damage the natural environment must not be undertaken in habitat protection areas. Dams and artificial impoundments give rise to "new" habitats that some species may take advantage of. For example, the stream Emån in southern Sweden holds a population of Wels catfish (Silurus glanis L.), which is an endangered species. The catfish is considered to be a postglacial relict in this stream. Bushes of grey willow (Salix cinerea L.) proliferate in this impoundment, and the fish have been able to use their tangled roots as breeding and hiding habitats, thus surviving in the regulated stream. Generally, catfish need slow-flowing streams with natural river environments; water regulation is therefore a threat to the fish and its natural environment (Nathanson 1995).

Dams work as barriers that block the migration and dispersal of invasive as well as native species. Removal of a dam exposes a large area of reservoir sediment that is highly conducive to plant colonization, especially of invasive species. Aggressive plant colonists may dominate for several years if natives fail to survive because of strong competition (D'Antonio and Meyerson 2002, Shafroth et al. 2002, Orr and Stanley 2006). Connectivity is often lost in aquatic ecosystems because of dam construction. Consequently, seasonal migrations of aquatic organisms are prevented, and the diversity and productivity of aquatic habitats are reduced. On the other hand, by removing these barriers, river restoration may increase the homogenization of aquatic biotas by spreading non-native species. However, by restoring former impoundments to free-flowing stream reaches, fish composition will shift from lentic to lotic, thus increasing biotic diversity and allowing native species to return to their habitats (Rahel 2007). Some faunal changes may occur rapidly, whereas other long-term changes occur as species adjust to changes in the channel (Hart et al. 2002).

Riverine organisms are always more or less affected by dam removal before the state in the channel has stabilized. Freshwater mussels are generally the most negatively affected. Studies in Koshkonong Creek, Wisconsin, USA, showed that $95 \%$ of the mussels in the previously inundated area died because of exposure and dehydration, and one species disappeared entirely. Also, the mussels downstream from the dam were affected by the removal, and their density decreased from 3.8 to 2.6 mussels $/ \mathrm{m}^{2}$ in less than $3 \mathrm{yr}$ because of increased sedimentation (Sethi et al. 2004). The freshwater pearl mussel (Margaritifera margaritifera L.) is a red-listed and threatened species in Swedish streams. This species lives its larval stage on the gills of salmonid fish species, mainly brown trout (Salmo trutta L.), and would likely benefit in the long term from dam removal because this facilitates trout migration. However, it is important to consider the amount of sediment that could affect populations located downstream. Elm (2004) concluded that, despite the obvious benefits of removing the Örby sawmill in Ljungån, Sweden, this could potentially harm populations of freshwater pearl mussels in the stream, because of both increased sedimentation and the leakage of toxic waste from the former sawmill, and cautioned against removal without a thorough investigation of the harm it could potentially cause.

\section{RECOMMENDATIONS}

Adequately applied, environmental legislation should ensure that future generations will be able to enjoy natural communities, free-flowing waters, and thriving landscapes. One would imagine that the removal of artificial objects from running waters would generally be seen as a good thing, especially in cases in which these objects no longer have any socioeconomic value. However, in a surprisingly large number of cases, this is not how dam removal is perceived, and public perceptions of dam removal and its consequences may seriously impede removal projects. Although there are many reasons for this resistance, they need to be understood to find solutions that will benefit both nature and human societies. Below, we present two basic tools that could assist in this process.

First, reliable information about the effects of dams and the effects of removing them is required. So far, 
Fig. 3. Unnefors Dam on the Nissan Stream before removal.

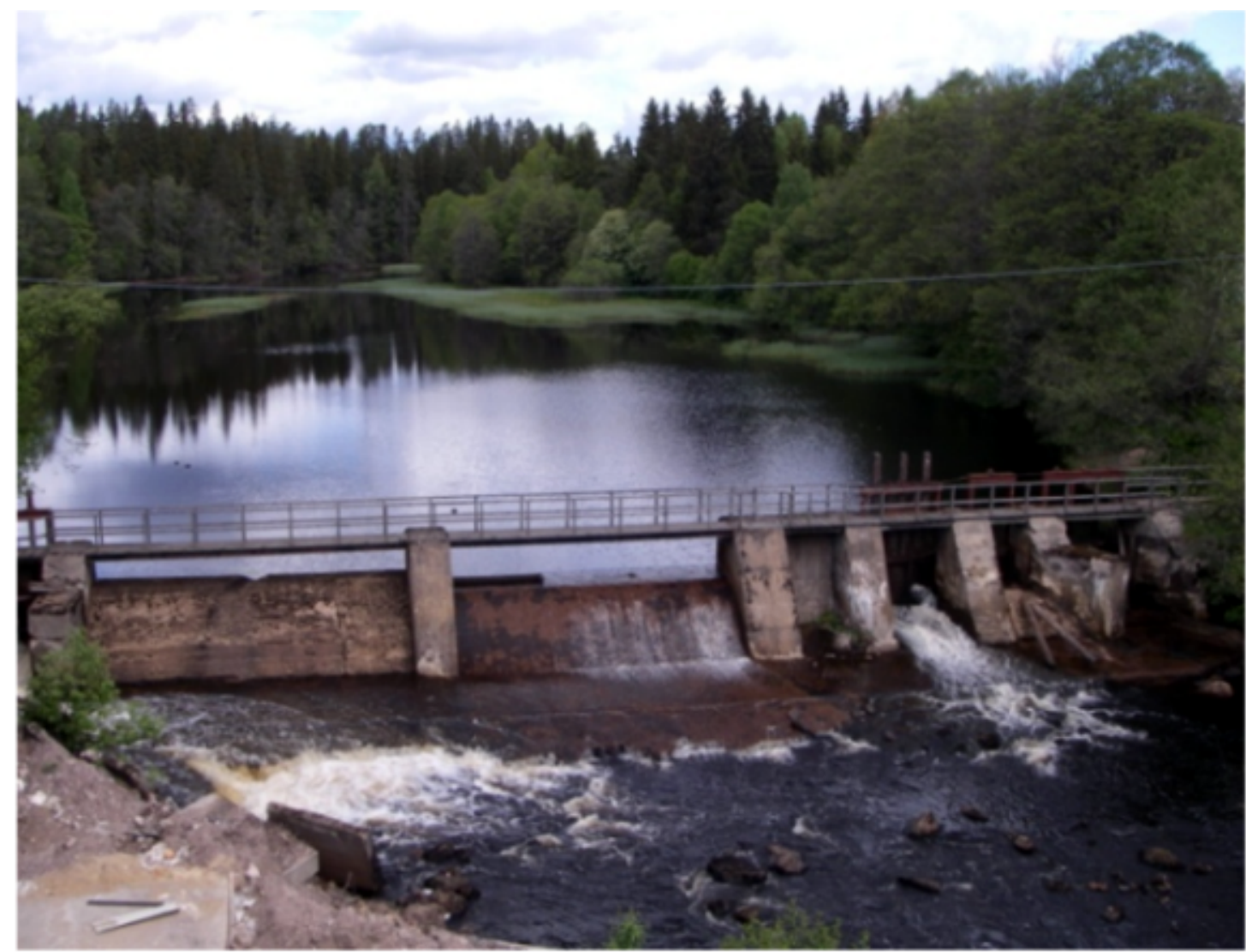

the idea of dam removal is unfamiliar to the general public. Although dams are often seen as monuments that should last (Babbitt 2005), it is reasonable to ask whether it is realistic to preserve every old dam, or whether there are ways to conserve the cultural values of dams without making them into untouchable monuments. As described above, there was strong opposition to the removal of the Bruksfallet and Bultfallet dams for culturalhistorical reasons, and these dams are to be preserved unconditionally. However, there are dam removals in which only pieces of the dam will be preserved for historic purposes (David and Baish 2002), such as the Glen Canyon Dam on the Elwha River. The obvious advantages of dams, such as electricity generation and the creation of recreational lakes, make it difficult to assess their potential ecological damage, so that the eventual benefits of dam removal may not be obvious. Facilitation of fish migration and spawning is generally an important reason for dam removal, and it is also reasonably well understood. Game fish are much easier to relate to than general ecosystem qualities such as "increasing biodiversity." Thus, the careful formulation of the reasons for dam removal and adequate education of the public are important tasks that must be undertaken in each case.

Second, stakeholder involvement is important. As our results suggest, the involvement of a variety of stakeholders increases their willingness to find compromises, thus avoiding conflicts. An example of this is the Unnefors Dam on Nissan stream (Figs. 3 and 4). In this case, the dam owner, a sawmill company, agreed to co-finance the removal if they were allowed to extend their timber yard. This required a new channel stretch, and adjacent neighbors were invited to influence its design. At first, people opposed the removal, but education and 
Fig. 4. Nissan Stream after dam removal in July 2008. The channel is being redug (to the right in the picture) so that the sawmill can expand its log yard out into the natural stretch. This was a demand from the company in return for co-financing and agreeing to the removal. A and B mark the banks that will be removed when the new channel becomes operational.

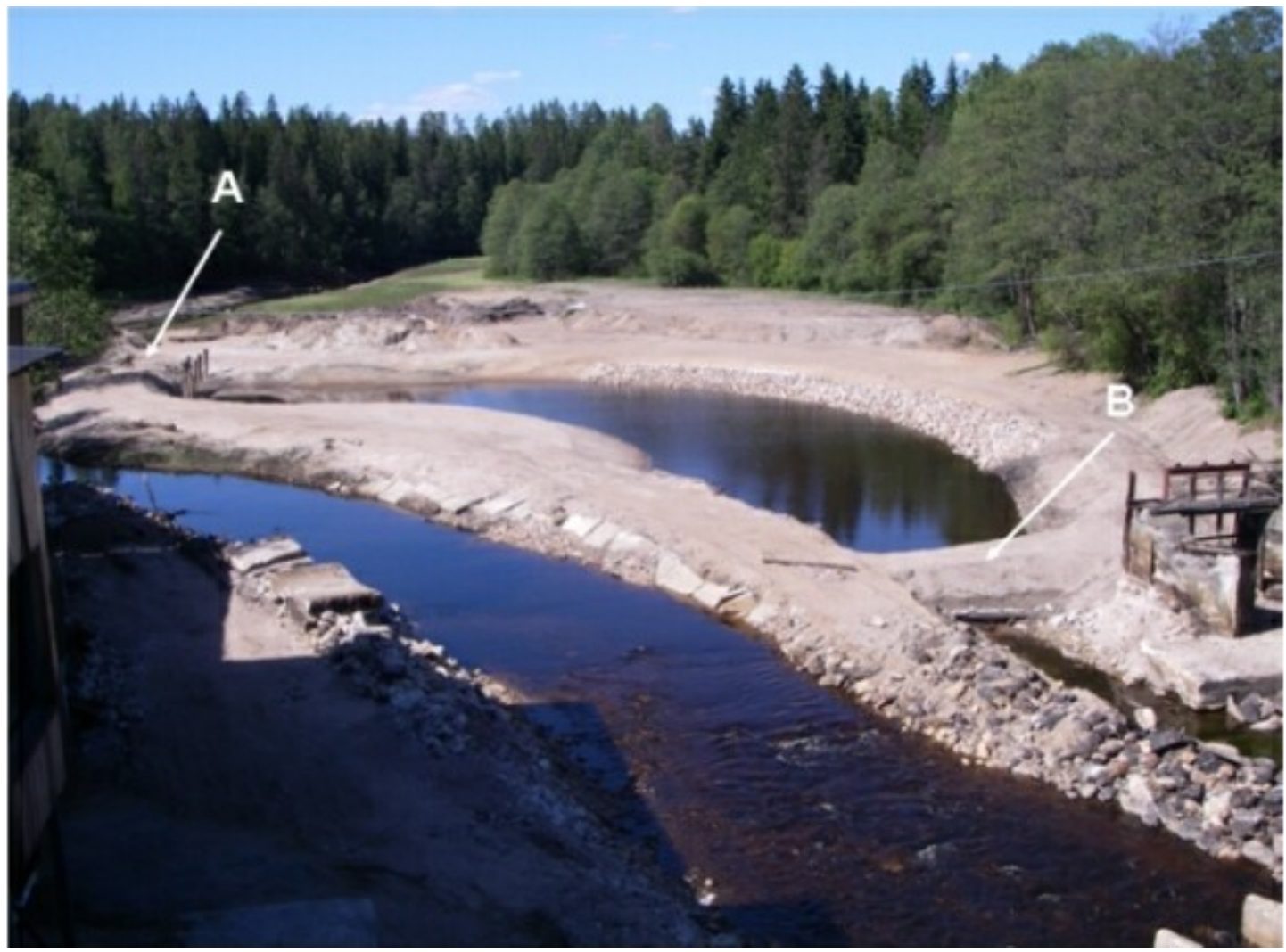

encouragement to get involved made them change their minds. Especially in complicated cases in which the goal is a compromise, the integration of the knowledge of a diversity of stakeholders is crucial for any outcome other than maintaining the status quo. When those involved do not have a clear understanding of what will happen when a dam is removed, it can be hard to get different actors, such as municipal offices, county administration boards, research groups, and power companies, to cooperate with each other. This may lead to overlapping work, conflicts with stakeholders, and missed opportunities to study the effects of dam removals. Again, in the example of Bruksfallet and Bultfallet, the provision of adequate information about safety issues related to the deteriorating dams and the ecological benefits of removing them could have avoided several controversies.
More information should also be provided to researchers. It is not uncommon for researchers to be notified about a removal at such a late stage that they have no time to carry out pre-removal studies, which are fundamental for evaluating post-removal recovery processes. In some cases, a removal may be debated for years but carried out almost immediately once the decision has been made, thus limiting opportunities to conduct more extensive studies. In contrast, researchers also run into problems when they have begun pre-removal studies and removal plans are cancelled or put on hold for years. In the case of Gate kvarndamm on Gatebäcken, time and money could have been saved if the municipality had drawn up a financial plan ahead of time. That way, unexpected and constantly recurring expenses might have been avoided, giving those involved a better opportunity to acquire and 
allocate recourses and a better chance for a successful removal. The fact that dam removal studies can be joint ventures has to be taken into consideration during research planning. Close collaboration with all the bodies involved in dam removal operations is the key to responsible use of research resources.

When dealing with dam removals, the problems in Sweden and the United States are similar. There are no guidelines on how to approach dam removals and troubleshoot problems, nor are there any longterm studies to learn from, especially in the case of Sweden, where dam removal still is in its infancy. Hart et al. (2002) give an example of a risk assessment framework for evaluating the potential effects of dam removal. It is suggested that this framework, under the right circumstances, can be used to take into account many of the factors that influence variations in potential responses to dam removal. Even so, in both Sweden and the United States, effective river restoration is only accomplished when there is co-operation between various protection and restoration practices. The issues we have examined are unique because they are Swedish examples and experiences, but also because they are the first ones that have involved researchers actively working with dam removals and river restoration in Sweden. In fact, every dam removal is unique, but the experiences gained are applicable to almost any removal. Therefore, sharing those experiences and making thorough field and data analyses are of great importance globally. Finally, whatever happens to dams in the future, the dam removal movement will challenge dam owners and operators to defend themselves, and "to demonstrate by hard facts, not by sentiment or myth, that the continued operation of a dam is in the public interest, economically and environmentally" (Klein 1999).

Responses to this article can be read online at:

http://www.ecologyandsociety.org/vol14/iss2/art4/responses/

\section{Acknowledgments:}

This research was supported by the Swedish Society of Nature Conservation, the Swedish World Wide Fund for Nature, and the Lamm Foundation. We thank Rebecca Brown, James Helfield, and two anonymous reviewers for constructive comments on the manuscript.

\section{LITERATURE CITED}

Acou, A., P. Laffaille, A. Legault, and E. Feunteum. 2008. Migration pattern of silver eel (Anguilla anguilla) in an obstructed river system. Ecology of Freshwater Fish 17:432-442.

Babbitt, B. 2002. What comes up, may come down. BioScience 52:656-658.

Babbitt, B. 2005. Cities in the wilderness: a new vision of land use in America. Island Press, Washington, D.C., USA.

Blumm, M. C., and V. A. Nadol. 2001. The decline of the hydropower czar and the rise of agency pluralism in hydroelectric licensing. Columbia Journal of Environmental Law 81:81-130.

Born, S. M., K. D. Genskow, T. L. Filbert, N. Hernandez-Mora, M. L. Keefer, and K. A. White. 1998. Socioeconomic and institutional dimensions of dam removals: the Wisconsin experience. Environmental Management 22:359-370.

Bradshaw, G. A., and M. Bekoff. 2001. Ecology and social responsibility: the re-embodiment of science. Science and Society 16:460-465.

Coutant, C. C., and R. R. Whitney. 2000. Fish behavior in relation to passage through hydropower turbines: a review. Transactions of the American Fisheries Society 129:351-380.

D'Antonio, C., and L. A. Meyerson. 2002. Exotic plant species as problems and solutions in ecological restoration: a synthesis. Restoration Ecology 10:703-713.

David, S. D., and S. Baish, editors. 2002. Dam removal: science and decision making. H. John Heinz III Center on Science, Economics and the Environment, Washington, D.C., USA.

Degerman, E., J. Hammar, P. Nyberg, and G. Svärdson. 2001. Human impact on the fish diversity in the four largest lakes of Sweden. Ambio 8: $522-528$.

Duda, J., S. Brenkman, C. Orgersen, J. Dunham, R. Hoffman, R. Peters, M. McHenry, and G. Press. 2008. Impending removal of Elwha Dam holds promise for salmon, researchers. People, Land and Water. Available online at: http://www.pe oplelandandwater.gov/scienceandstewardship/ 
usgs 12-19-08 impending-removal-of.cfm.

Dudgeon, D. 1995. River regulation in southern China: ecological implications, conservation and environmental management. Regulated Rivers: Research and Management 11:35-54.

Dunagan, C. 2008. Dam closer to coming down; price for removal shoots up. Kitsap Sun. Available online at: http://www.kitsapsun.com/news/2008/feb/06/ dam-closer-to-coming-down-price-for-removal-up/.

Einsele, G., and M. Hinderer. 1997. Terrestrial sediment yield and the lifetimes of reservoirs, lakes, and larger basins. Geologische Rundschau 86:288-310.

EIm, A. 2004. En dammrivnings effekter på flora och fauna $i$ och längs en å. Ljungaån, Marks kommun. Thesis. Gothenburg University, Gothenburg, Sweden.

Emanuel, K. 2005. Increasing destructiveness of tropical cyclones over the past 30 years. Nature 436:686-688.

Ericson, J. P., C. J. Vörösmarty, S. L. Dingman, L. G. Ward, and M. Meybeck. 2006. Effective sealevel rise and deltas: cause of change and human dimension implications. Global and Planetary Change 50:63-82.

European Commission. 1992. Council Directive 92/43/EEC of 21 May 1992 on the conservation of natural habitats and of wild fauna and flora. European Commission, Brussels, Belgium.

European Commission. 2000. EU Water Framework Directive 2000/60/EC of 22 December 2000 on integrated river basin management for Europe. European Commission, Brussels, Belgium.

Evans, J. E., S. D. Mackey, J. F. Gottgens, and W. M. Gill. 2000. Lessons from a dam failure. Ohio Journal of Science 100:121-131.

Fearnside, P. M. 1997. Greenhouse-gas emissions from Amazonian hydroelectric reservoirs: the example of Brazil's Tucurui Dam as compared to fossil fuel alternatives. Environmental Conservation 24:64-75.

Gawley, B. 2008. Elwha dam removal project cost rising to $\$ 308$ million. Peninsula Daily News.
Available online at: http://www.peninsuladailynews. com/article/20080206/NEWS/802060303.

Gowan, C., K. Stephenson, and L. Shabman. 2006. The role of ecosystem valuation in environmental decision making: hydropower relicensing and dam removal on the Elwha River. Ecological Economics 56:508-523.

Graf, W. L., editor. 2003. Dam removal research: status and prospects. H. John Heinz III Center for Science, Economics and the Environment, Washington, D.C., USA.

Gregory, S., H. Li, and J. Li. 2002. The conceptual basis for ecological responses to dam removal. BioScience 52:713-723.

Hart, D. D., and N. L. Poff. 2002. A special section on dam removal and river restoration. BioScience 52:643-738.

Hart, D. D., T. E. Johanson, K. L. BushawNewton, R. J. Horwitz, A. T. Bednarek, D. F. Charles, D. A. Kreeger, and D. J. Velinsky. 2002. Dam removal: challenges and opportunities for ecological research and river restoration. BioScience 52:669-681.

Hörnström, E. 2009. Plant recolonization following dam removal: a phytometer experiment. Thesis. Umeå University, Umeå, Sweden.

Jansson, R., C. Nilsson, M. Dynesius, and E. Andersson. 2000. Effects of river regulation on river-margin vegetation: a comparison of eight boreal rivers. Ecological Applications 10:203-224.

Johnson, P. T. J., J. D. Olden, and M. J. Vander Zanden. 2008. Dam invaders: impoundments facilitate biological invasions into freshwaters. Frontiers in Ecology and the Environment 6:357-363.

Kareiva, P., M. Marvier, and M. McClure. 2000. Recovery and management options for spring/ summer Chinook salmon in the Columbia River Basin. Science 290:977-979.

Kelly, C. A., J. W. M. Rudd, R. A. Bodaly, N. P. Roulet, V. L. St. Louis, A. Heyes, T. R. Moore, S. Schiff, R. Aravena, K. J. Scott, B. Dyck, R. Harris, B. Warner, and G. Edwards. 1997. Increases in fluxes of greenhouse gases and methyl mercury following flooding of an experimental 
reservoir. Environmental Science and Technology 31:1334-1344.

Kingsford, R. T. 2000. Ecological impacts of dams, water diversions and river management on floodplain wetlands in Australia. Austral Ecology 25:109-127.

Klein, C.A. 1999. On dams and democracy. Oregon Law Review (Fall 1999). Abstract available online at: http://papers.ssrn.com/sol3/papers.cfm? abstract id=1266162.

Kruse, S. A., and A. J. Scholz. 2006. Preliminary economic assessment of dam removal: the Klamath River. Ecotrust, Portland, Oregon, USA.

Laffaille, P., A. Acou, J. Guillouet, and A. Legault. 2005. Temporal changes in European eel, Anguilla anguilla, stocks in a small catchment after installation of fish passes. Fisheries Management and Ecology 12:123-129.

Laitila, T., A. Jonsson, and A. Paulrud. 2006. Regleringsdammen vid Storsjö-Kapell. Sportfiskarnas värdering av ett återställande till naturligtfjällfiske. FjällMistra Report Number 19. FjällMistra, Umeå, Sweden.

McCully, P. 2001. Silenced rivers: the ecology and politics oflarge dams. St. Martin's Press, New York, New York, USA.

Morin, F. 2006. Vattenkraft samhällsekonomiskt lönsamt? En studie om hur samerna, sportfisketurismen och miljön påverkas av en vattenkraftsutbyggnad $i$ Kalixälven. Thesis. Luleå University of Technology, Luleå, Sweden.

Nathanson, J. E. 1995. Malens (Silurus glanis) reproduktions-och uppväxtplatser i Sverige samt förslag till åtgärder för dess överlevnad. Information från Sötvattenslaboratoriet Drottningholm 3:1-41.

National Park Service. 2007. National Park Service awards contract for the Elwha water facilities. Available online at: http://www.nps.gov/ olym/parknews/national-park-service-awards-contractfor-the-elwha-water-facilities.htm.

Nilsson, C., and K. Berggren. 2000. Alterations of riparian ecosystems caused by river regulation. BioScience 50:783-792.
Nilsson, C., R. Jansson, and U. Zinko. 1997. Long-term responses of river-margin vegetation to water-level regulation. Science 276:798-800.

Nilsson, C., C. A. Reidy, M. Dynesius, and C. Revenga. 2005. Fragmentation and flow regulation of the world's large river systems. Science 308:405-408.

Orr, C. H., and E. H. Stanley. 2006. Vegetation development and restoration potential of drained reservoirs following dam removal in Wisconsin. River Research and Applications 22:281-295.

Palmer, M. A., C. Reidy Liermann, C. Nilsson, M. Flörke, J. Alcamo, P. S. Lake, and N. Bond. 2008. Climate change and the world's river basins: anticipating management options. Frontiers in Ecology and the Environment 6:81-89.

Pess, G. R., M. L. McHenry, M. L., Beechie, T. J. and Davies, J. 2008. Biological impacts of the Elwha River dams and potential salmonid response to dam removal. Northwest Science 82:72-90.

Provencher, B., H. Sarakinos, and T. Meyer. 2008. Does small dam removal affect local property values? An empirical analysis. Contemporary Economic Policy 26:187-197.

Rãdoane, M., and N. Rãdoane. 2005. Dams, sediment sources and reservoir silting in Romania. Geomorphology 71:112-125.

Rahel, F. J. 2007. Biogeographic barriers, connectivity and homogenization of freshwater faunas: it's a small world after all. Freshwater Biology 52:696-710.

Revenue Stream. 2008. An economic analysis of the costs and benefits of removing the four dams on the lower Snake River. Available online at: http://w ww.wildsalmon.org/index.php?option= com content\&view-article\&id=70.

RiverNet. 2008. The Saint Etienne de Vigan Dam and the Maison Rouge Dam dismantled for Salmon. European Rivers Network. Available online in: htt $\mathrm{p}: / / \mathrm{ww}$.rivernet.org/general/dams/decommissioni ng fr hors poutes/stedvig.htm.

Ruwitch, J. 2008. China rushes to fix dams; 9,000 sq miles flooded. Reuters AlertNet. Available online at: http://www.alertnet.org/thenews/newsdesk/ PEK120395.htm. 
Sarakinos, H., and S. E. Johnson. 2003. Social perspectives on dam removal. Pages 40-55 in W. L. Graf, editor. Dam removal research: status and prospects. H. John Heinz III Center for Science, Economics and the Environment, Washington, D. C., USA.

Scudder, T. 2005 The future of large dams; dealing with social, environmental, institutional and political costs. Earthscan, London, UK.

Sethi, S. A.,A. R. Selle, M. W. Doyle, E. H.Stanley, and H. E. Kitchel. 2004. Response of unionid mussels to dam removal in Koshkonong Creek, Wisconsin (USA). Hydrobiologia 525:157-165.

Shafroth, P. B., J. M. Friedman, G. T. Auble, M. L. Scott, and J. H. Braatne. 2002. Potential responses of riparian vegetation to dam removal. BioScience 52:703-712.

Shuman, J. R. 1995. Environmental considerations for assessing dam removal alternatives for river restoration. Regulated Rivers: Research and Management 11:249-261.

Stanford, J. A., J. V. Ward, V. J. Liss, C. A. Frissell, R. N. Williams, J. A. Lichatowich, and C. C. Coutant. 1996. A general protocol for restoration of regulated rivers. Regulated Rivers: Research and Management 12:391-413.

Stanley, E. H., and M. W. Doyle. 2003. Trading off: the ecological effects of dam removal. Frontiers in Ecology and the Environment 1:15-22.

Stewart-Oaten, A., W. W. Murdoch, and K. R. Parker. 1986. Environmental impact assessment: "pseudoreplication" in time? Ecology 67:929-940.

St. Louis, V. L., C. A. Kelly, E. Duchemin, J. W. M. Rudd, and D. M. Rosenberg. 2000. Reservoir surfaces as sources of greenhouse gases to the atmosphere: a global estimate. BioScience 50:766-775.

Sundberg, S., and T. Söderqvist. 2004. The economic value of environmental change in Sweden. Swedish Environmental Protection Agency Report Number 5360. Swedish Environmental Protection Agency, Stockholm, Sweden.

Swedish Board of Fisheries. 2008. Sik (Coregonus lavaretus). Available online at: http://www.fiskeriv erket.se/vanstermeny/fiskochskaldjur/arter/allaarter/ sikcoregonuslavaretus.html.

Swedish Government. 2008. Available online at: http://www.miljomal.nu/Environmental-ObjectivesPortal.

Swedish Meteorological and Hydrological Institute (SMHI). 1994. Svenskt dammregister: södra Sverige. Svenskt Vattenarkiv Number 55. SMHI, Norrköping, Sweden.

Swedish Meteorological and Hydrological Institute (SMHI). 1995. Svenskt dammregister: norra Sverige. Svenskt Vattenarkiv Number 56. SMHI, Norrköping, Sweden.

Syvitski, J. P. M., C. J. Vörösmarty, A. J. Kettner, and P. Green. 2005. Impact of humans on the flux of terrestrial sediment to the global coastal ocean. Science 308:376-380.

University of Idaho. 2008. History of Elwha and Glines Canyon dams. Elwha Watershed Information Resource. Available online at: http://w ww.elwhainfo.org/elwha-river-watershed/dam-removal/ history-elwha-and-glines-canyon-dams.

U.S. Geological Survey. 2008. Magnitude 7.9Eastern Sichuan, China. Available online at: http:// earthquake.usgs.gov/eqcenter/eqinthenews/2008/ us2008ryan/\#details.

Vattenportalen. 2007. Vattenkraft och stora dammar. Available online at: http://www.vattenpor talen.se/fov problem vattenkraft.htm.

Ward, J. V., and J. A. Stanford. 1995. Ecological connectivity in alluvial river ecosystems and its disruption by flow regulation. Regulated Rivers: Research and Management 11:105-119.

World Commission on Dams (WCD). 2000. Dams and development: a new framework for decisionsmaking. Earthscan, London, UK.

Webster, P. J., G. J. Holland, J. A. Curry, J. A. and H.-R. Chang. 2005. Changes in tropical cyclone number, duration, and intensity in a warming environment. Science 309:1844-1846.

Whitelaw, E., and E. Macmullan. 2002. A framework for estimating the costs and benefits of dam removal. BioScience 52:724-730. 
World Wide Fund for Nature (WWF). 2004.

Rivers at risk: dams and the future of freshwater ecosystems. WWF, Godalming, UK. Available online at: http://www.panda.org/downloads/freshwater/ riversatriskfullreport.pdf. 